\title{
Pediatric Gastroenterology in Cuba: Evolution and Challenges
}

\author{
Carlos Castañeda-Guillot MD
}

\begin{abstract}
INTRODUCTION The professional practice of pediatric gastroenterology arose in Cuba as an expression of the specialty's development internationally and Cuba's new strategies in public health, and in response to national needs for health care expertise in digestive diseases of infants, older children and adolescents.
\end{abstract}

OBJECTIVES Describe the history of pediatric gastroenterology's development in Cuba since its inception at the National Gastroenterology Institute in the early 1970s, its contributions, and efforts to extend it to pediatric hospitals throughout Cuba.

EVIDENCE ACQUISITION This is a historical review based on document analysis. Institutional sources from the National Gastroenterology Institute and Ministry of Public Health were reviewed, as well as international and national literature on the history of pediatric gastroenterology and unpublished texts since its emergence in 1972.

DEVELOPMENT Although pediatric gastroenterology has not been formally recognized as a medical specialty in Cuba, there have been important achievements in establishing a network of specialized health care services for digestive diseases of children and adolescents. Gastrointestinal endoscopy and other auxiliary diagnostic modalities have been introduced for children and play a major role in clinical trials and research. This article describes the international context that promoted the specialty's development in Cuba. Reference is made to specialized training from its initial stages in 1972, its consolidation as an emerging discipline in Cuban medicine, and its diffusion in Latin American and Caribbean countries. Professional development and specialized training to meet health human resource needs in pediatric hospitals are described, as well as Cuban participation in the Latin American Society for Pediatric Gastroenterology, Hepatology and Nutrition. National and international milestones, publications, awards and recognitions that indicate advances despite difficulties are also presented.

CONCLUSIONS Since 1972, there have been major strides in the development of pediatric gastroenterology practice in Cuba. The establishment of a national network of specialized services in pediatric hospitals throughout Cuba has provided quality health care for digestive diseases of childhood. Pediatric gastroenterology's development and achievements in healthcare and research are such that it deserves official recognition as a medical specialty Cuba.

KEYWORDS Pediatric gastroenterology, history of medicine, national health system, service network, hepatology, children, adolescents, Cuba

\section{INTRODUCTION}

Pediatric gastroenterologists are physicians who specialize in management of digestive system disorders in children, from birth to the end of adolescence. They approach their medical practice from a pediatric perspective and grounding in clinical gastroenterology, aided by diagnostic technologies for examining the digestive system. Such procedures allow direct examination of the upper digestive tract through esophageal gastroduodenoscopy (for tissue sample collection by mucosal biopsy and esophageal dilation in stenosis), and ileocolonoscopy of the colon and distal small intestine.

Pediatric gastroenterology (PG) specialists perform resections of intestinal polyps; deal with liver, biliary tract and pancreatic diseases; and perform percutaneous and laparoscopic liver biopsies. They also handle comprehensive management of chronic liver diseases, including chronic hepatitis, liver cirrhosis and other genetically caused conditions, and use sclerotherapy or band ligation to treat varices due to portal hypertension or other causes. They perform infant cholestasis and related surgery, including liver transplantation. Pediatric gastroenterologists dedicated to liver and bile duct conditions are recognized as pediatric hepatologists; pediatric hepatology has emerged as a subspecialty of $P G$ in some countries.[1-4]

By the early 1970s, knowledge had developed and the international pediatric community, especially in continental Europe, the UK and North America, recognized the need for different pediatric subspecialties. Applied technology's contributions to the study of organs and systems, and the experience derived from more accurate diagnosis and improved treatment, were decisive for this recognition.
Today knowledge and experience regarding digestive system growth and development have led to a need for specific medical care. The emergence of PG as a subspecialty is in effect the joining of two medical specialties, pediatrics and gastroenterology, the product of medical scientific and technical progress for better quality and specificity of medical care for this age group.[5] PG has had limited growth in developing countries, but its future there is promising.[1-3]

This paper's objective is to present the historical evolution of $P G$ in Cuba (including its international context), from its beginnings in the early 1970s at the National Gastroenterology Institute (ING), reviewing the evolution of professional PG practice, its most relevant results in health care and science, and challenges for its extension to pediatric hospitals throughout Cuba.

\section{EVIDENCE ACQUISITION}

Institutional sources from ING and the Ministry of Public Health (MINSAP) were reviewed, as well as international and national literature on the history of PG and unpublished texts since PG's emergence in 1972. Personal records of the author, an eyewitness to most PG milestones in Cuba, were also reviewed.

\section{DEVELOPMENT}

Background Specialized care for childhood digestive disorders emerged in Europe in the 18th century, later in North America. Samuel Gee, a renowned doctor at the Saint Bartholomew Hospital (London), who attended both adults and children, is considered one of the forefathers of European pediatrics and of PG. In 1888, he described chronic diarrhea as the main manifestation of celiac disease in childhood.[1] 


\section{Review Article}

In the 1960s, after gastroenterology and pediatrics had been established as separate specialties, PG appeared as a specialty internationally because of the need for more highly specialized medical care, facilitated by the advent of the first fiber optic endoscopes for pediatric use. In Latin America, Argentina and Brazil were pioneers in the establishment of the specialty at the end of that decade.[6] PG was certified as a specialty in the USA in 1980 and approved as a medical subspecialty in 1990, under the auspices of the North American Association of Pediatric Gastroenterology, Hepatology and Nutrition (NASPGHAN).[1,5-8]

Distinguished pediatricians such as Harry Shwachman played a decisive role in training the first PG specialists. Expert teachers, such as Arnold Silverman and Allan Walker in the USA, Charlotte Anderson in Australia, Claude Roy in Canada and Jean Francois Rey in France, together with other outstanding Europeans in Finland, Switzerland, Sweden and Germany, played a major role in achieving recognition of $P G$ as a subspecialty. In parallel, pediatric hepatology emerged and developed as part of PG; leading players were Daniel Alagille in France, Alex Mowat in the UK, and Frederick Suchy and William Balistreri in the USA, all known for their clinical and teaching activities and for authoring landmark books that played a key role in development of specialized management of diseases of the gallbladder and liver (including transplantation).[9-11] The first comprehensive text on PG was published in 1971: Pediatric Clinical Gastroenterology, by Arnold Silverman, Claude C. Roy and Frank J. Cozzetto. It was also the first textbook used by Cuban pediatric gastroenterologists.[12]

PG in Cuba In 1970, Raimundo Llanio Navarro initiated the Medical Working Group on Pediatric Gastroenterology at ING (of which he was founder and director). In 1972, with the help of pediatrician Eladio Blanco Rabasa, the Pediatric Gastroenterology Service, the first of its kind in Cuba, was established at ING for specialized medical care, applied research and teaching.[13] This constituted the first step in PG development in Cuba as a subspecialty derived from gastroenterology. The first three doctors with pediatric experience (having had a year of pediatric residency) were gradually incorporated in ING from 1970 and trained for two additional years in gastroenterology for pediatric application (ING, unpublished institutional records). They effectively founded PG in Cuba, and consolidated its practice with their scientific activity.

PG's development was facilitated by Cuba's interest in diversifying public health. Pediatric wards had already been established in rural hospitals and the National Maternal-Child Health Program was established in 1970,[14] which particularly addressed the fight against gastroenteritis, among other diseases of great impact on childhood morbidity and mortality. It also promoted vaccination plans, among various new public health tasks taken on with implementation of the unified, universal and free National Health System (SNS) after 1959.[15]

At the same time, the three newly trained physicians in ING's PG service underwent further training: in France, with Alagille, pediatric hepatologist at the Bicêtre University Hospital in Paris (1972-73); in the UK with Charlotte Anderson at the Institute of Child Health in Birmingham (1973), at the Leicester Royal Infirmary (1978) with A.S. McNeish, a specialist in intestinal diseases; and in Mexico with Leopoldo Vega Franco at the Children's Hospital of Mexico (1974) (ING, unpublished institutional records). The intensive training and knowledge acquired with these professors were decisive contributions to PG's development in Cuba.

It is worth emphasizing the influence of this initial group of doctors specializing in the study of diseases that were infrequent at the time: their impact on pediatric medical research, postgraduate education of PG specialists for pediatric hospitals in Cuba's capital and provinces, and the organization of a national network of PG care. The new PG Service quickly became a national reference center for treating childhood digestive disorders.

Specialized care for children and adolescents with a range of digestive diseases was crucial, particularly use of digestive system endoscopy for diagnostic and therapeutic purposes. For conditions of intestinal origin (such as celiac disease), diagnosis required introduction of peroral jejunal biopsy using the pediatric Crosby-Watson capsule, and colonoscopy to study colon pathologies such as ulcerative colitis and Crohn disease (ING, unpublished institutional records). These methods represented new contributions to health care in Cuba.

Progress in treatment of liver diseases, such as chronic hepatitis $B$, also deserves mention; e.g., with laparoscopic studies and liver biopsy. Cuba was a pioneer in Latin America and the Caribbean in treating chronic hepatitis B with domestically produced interferon. Initially, natural interferon alpha was used and later recombinant interferon alpha, both obtained at the Genetic Engineering and Biotechnology Center in Havana starting in the early 80 s. The resulting clinical trials had international impact.[16,17] The introduction of diagnosis of rare liver diseases, such as Alagille syndrome,[18] Wilson disease[19] and alpha-1-antitrypsin deficiency[20] were also achievements by ING's PG specialists, in collaboration with biochemists, biologists and anatomic pathologists.

The most important event for Cuban PG in the past decade was the establishment of the Pediatric Liver Transplant Unit by a multidisciplinary medical team at the William Soler Pediatric University Hospital in Havana, in 2005 (ING, unpublished institutional records).

In Cuba, PG is not yet officially recognized as a specialty. There is only the gastroenterology residency, offered by the Medical University of Havana and the provincial medical universities. ING is recognized as Cuba's national PG reference center and provides specialized training in endoscopic diagnosis and treatment for pediatric patients, as well as digestive system biopsy, treatment of varices, laparoscopy, percutaneous liver biopsy, interpretation of esophageal and anorectal manometry, and up-to-date management of digestive system diseases. A PG training program lasting 18-24 months, focusing mainly on digestive system endoscopy, has also been offered to pediatricians (ING, unpublished institutional records).

\section{PG services in Cuban pediatric hospitals}

First stage The first specialized PG service in a Cuban hospital was established at the William Soler Pediatric University Hospital in Havana in the late 1970s. Of particular relevance was the performance of endoscopies, liver and jejunal biopsies and other special procedures, carried out by two ING-trained pediatricians (MINSAP, unpublished institutional records).

In the cities of Santa Clara and Santiago de Cuba, in central and eastern Cuba, respectively, PG services had been organized 
since the end of the 1970 s by training pediatricians, who performed valuable clinical and endoscopic work.

Second stage During the 1980s, at the request of ING pediatric gastroenterologists, a project for PG development was initiated, with three main components: 1) scientific-technical development, 2) prioritized specialty training, and 3) extension of $P G$ services to all pediatric hospitals in Cuba, with acquisition of modern fiberoptic endoscopy equipment, so that only children requiring specialized studies not available in their province need be transferred to Havana. Thus, services with modern equipment purchased in Japan by the Ministry of Public Health (MINSAP) for Cuban pediatric hospitals were established, initially in the cities of Santa Clara, Camagüey and Holguin (ING and MINSAP, unpublished institutional records).

In 1984, a PG service was organized in the Holguín's Octavio de la Concepción de la Pedraja Pedriatic University Hospital, led by ING-trained Dr. José Soler Franco, chief of service. He established the Digestive Endoscopy Unit and the PG ward, which provides patient care for Holguín and neighboring provinces, as well as PG courses for pediatricians. This service is a reference center for childhood digestive pathology in eastern Cuba (ING and MINSAP, unpublished institutional records).

Also during the 1980s, PG services were established in five pediatric hospitals in Havana, after ING trained pediatricians in gastroenterology (ING and MINSAP, unpublished institutional records). The Pedro Borrás-Marfán Pediatric Teaching Hospital succeeded in establishing a PG service, with a modern ambulatory endoscopy unit, and provided quality health care by gastroenterologists trained as pediatric gastroenterologists. PG services in the other four hospitals had to face shortage of PG specialists and reduced availability of pediatric endoscopy equipment. To date, only Centro Habana Pediatric Teaching Hospital continues to provide PG services (Author's personal records).

In October 1989 Havana's Juan Manuel Márquez Pediatric University Hospital opened a PG service with modern Japanese endoscopy equipment and three medical specialists, two of them trained in ING's Pediatrics Department. Within a few years this unit became a highly specialized service that offered courses and workshops, and successfully developed endoscopic and clinical activity (MINSAP, unpublished institutional records).

The provincial hospitals of Ciego de Ávila, Cienfuegos, Sancti Spíritus, Matanzas and Pinar del Rio had already begun to provide PG care. Subsequently, many of these hospitals gradually expanded their cadre of $P G$ specialists, sending other pediatricians for training at ING or at Juan Manuel Márquez Pediatric University Hospital's Department of Gastroenterology (MINSAP, unpublished institutional records).

Barriers MINSAP has had great limitations in its capacity to purchase, repair or replace endoscopy equipment (such as pediatric endoscopic capsules), because of obstacles to acquiring parts on the international market due to the long-standing US embargo. It has also had difficulty acquiring other modern equipment, such as expired-hydrogen monitors to measure esophageal $\mathrm{pH} .[21]$

PG milestones in Cuba Cuban PG's scientific results are expressed in the organization and implementation of national scientific events; participation in international congresses; research awards and recognitions (which indicate the work's scientific rigor and have had substantial impact in the Latin American region); and in a considerable volume of monographs and scientific articles. Table 1 contains a detailed list of scientific and other events pertinent to the history of Cuban PG.

Among those events, the 9th Meeting of the Latin American Society of Gastroenterology, Hepatology and Nutrition (LASPGHAN), (Havana, 1989), stands out, both for its political and scientific significance. The representatives of Uruguay, the country selected to host the event, ceded their hosting rights to Cuba, in solidarity with Cuba because of its isolation in the Latin American context at the time, and to recognize Cuban PG accomplishments in health care and research. More than 250 physicians from Latin America attended, including members of LASPGHAN, as well as leading international PG experts.

So far this century, Cuban PG practitioners have been lead authors, writers or editors of important teaching and reference materials: books, articles, and chapters in more than a dozen books. [22-34] These, together with other publications in Cuban and international journals over more than four decades, are an indicator of Cuban PG professionals' scientific productivity. Some of the most important appear as references to this text.[35-51]

Challenges PG in Cuba, remains to be formally recognized as a medical subspecialty, following academic principles and programs established internationally for PG residency training. $[1,3-5,13]$ To date, pediatric gastroenterologists who complete pediatric training in addition to a gastroenterology residency have no recognition for their PG specialization. We urgently need to train new PG professionals to ensure the future of the specialty, which in the past decade has been affected by the retirement of the first generation of PG-dedicated physicians.

Other important tasks are consolidation of achievements in digestive system endoscopy (techniques requiring specific training), $[1,4,7]$ and rounding out $P G$ training with the basics of pediatric nutrition.[5,8]

The achievements of Cuban PG, both in its scientific production and its clinical practice have been attained despite the handicap of its historical origin in gastroenterology rather than pediatrics, which limits its growth. Cuba's sustained low rates of infant mortality also speak to PG's contributions.[52]

\section{CONCLUSIONS}

In 1972, Cuba was the first country in Central America and the Caribbean to develop the professional practice of PG as a de facto pediatric subspecialty. Its scientific and clinical contributions in providing quality management of digestive diseases in children, have had great impact, reflected in SNS's establishment of a national network of PG services in pediatric hospitals throughout Cuba. PG's development and achievements in healthcare and research are such that it deserves official recognition as a medical specialty Cuba.

\section{ACKNOWLEDGMENTS}

Our gratitude goes to Dr Trini Fragoso and Dr Eduardo Sagaró, PG pioneers in Cuba, for their help with this article. - 1h- 


\section{Review Article}

Table 1: Milestones (significant events and awards) of pediatric gastroenterology in Cuba

\begin{tabular}{|c|c|}
\hline Year & Event \\
\hline \multicolumn{2}{|c|}{ Cuban milestone } \\
\hline 1970 & Medical Working Group on Pediatric Gastroenterology created at ING \\
\hline 1972 & 1st pediatric gastroenterology service established in Cuba, ING[13] \\
\hline From 1975 & National and provincial PG conferences and workshops \\
\hline 1980 & 1st Cuban Congress of Pediatric Gastroenterology (within National Gastroenterology Congress) \\
\hline 1985 & 2nd Cuban Congress of Pediatric Gastroenterology (at National Gastroenterology Congress) \\
\hline 2010 & Creation of pediatric gastroenterology section of Cuban Gastroenterology Society \\
\hline \multicolumn{2}{|c|}{ International participation } \\
\hline 1984 & Precongress PG course at ALAPE \\
\hline 1989 & 9th Congress of Pediatric Gastroenterology and Nutrition sponsored by LASPGHAN, ING, Cuba \\
\hline 1989-2011 & $\begin{array}{l}\text { LASPGHAN congresses: Cuba (1989), Uruguay 1992, Venezuela 1994, Brazil 1996, Mexico 1998, Argentina 2001, Spain 2003, } \\
\text { Colombia 2005, Chile 2009, Dominican Republic } 2011\end{array}$ \\
\hline 1991 & Precongress PG course at AIGE-SIED \\
\hline 2000 & 1st WCPGHAN, sponsored by FISPGHAN (North American, European, Latin American and Asian-Pacific societies), USA \\
\hline 2004 & 2nd FISPGHAN Congress, France \\
\hline 2004 & International Working Group on Biotherapeutics and Nutraceutical Agents, 2nd WCPGHAN, France \\
\hline 2008 & 3rd FISPGHAN Congress, Brazil \\
\hline 2011 & $\begin{array}{l}\text { Cuba presides over 1st Caribbean Congress of Pediatric Gastroenterology, Hepatology and Nutrition (18th LASPGHAN and 9th } \\
\text { Iberian American Congress), Dominican Republic }\end{array}$ \\
\hline \multicolumn{2}{|r|}{ (2) } \\
\hline 1992 & $\begin{array}{l}\text { Recombinant interferon alfa-2b (domestic production) for chronic hepatitis due to } B \text { virus infection in childhood, first prize } \\
\text { (10th LASPGHAN Congress), Uruguay }\end{array}$ \\
\hline 2000 & National vaccination program against hepatitis B in children and adolescents in Cuba. (1st WCPGHAN) Boston, USA \\
\hline 2005 & $\begin{array}{l}\text { Impact of the National Immunization Program against hepatitis B. } \\
\text { 1992-2004 results. Cuban experience first prize (16th LASPGHAN, 7th Iberian and 1st Colombian Congress of Pediatric } \\
\text { Gastroenterology, Hepatology and Nutrition), Colombia }\end{array}$ \\
\hline 2011 & $\begin{array}{l}\text { Diagnostic efficacy of antitransglutaminase antibodies in children with chronic digestive symptoms and suspected celiac disease and } \\
\text { sequential therapy for Helicobacter pylori in infected school children and adolescents in an outpatient service, LASPGHAN prize } \\
\text { (18th LASPGHAN, 9th Iberian and 1st Caribbean Congress), Dominican Republic }\end{array}$ \\
\hline
\end{tabular}

Sources: ING institutional records and documents of Latin American and world congresses

AIGE-SIED: Inter-American Gastroenterology Association-Inter-American Digestive Endoscopy Society

ALAPE: Latin American Pediatrics Association

FISPGHAN: Federation of International Societies of Pediatric Gastroenterology, Hepatology and Nutrition

ING: National Gastroenterology Institute

LASPGHAN: Latin American Society for Pediatric Gastroenterology, Hepatology and Nutrition

WCPGHAN: World Congress of Pediatric Gastroenterology, Hepatology and Nutrition

\section{REFERENCES}

1. Walker-Smith J, Walker WA. The development of pediatric gastroenterology: a historical overview. Pediatr Res. 2003 Apr;53(4):706-15.

2. Worley LL, Cooper GJ, Fiser DH. Generational evolution and the future of pediatrics. J Pediatr. 2004 Aug;145(2):143-4.

3. Rezzónico CA. La Pediatría y sus especialidades: interrelación del pediatra y del especialista. Salud Infantil. 1993;3:76-80. Spanish.

4. Accreditation Council for Graduate Medical Education. ACGME Program Requirements for Graduate Medical Education in Pediatric Gastroenterology [Internet]. Chicago: ACGME; 2013 Jul 1 [cited 2016 Mar 21]. 7 p. Available from: http://www.acgme.org/acgmeweb/Portals/0/ PFAssets/2013-PR-FAQ-PIF/332_gastroentero logy_peds_07012013.pdf

5. Milla PJ. The European training syllabus in pediatric gastroenterology, hepatology, and nutrition. J Pediatr Gastroenterol Nutr. 2002 Feb;34(2):111-5.

6. Jorge JR. Historia de la Sociedad Latinoamericana de Gastroenterología, Hepatología y Nutrición Pediátrica (SLAGHNP/LASPGHAN). 35 Años de Historia. (1975-2010) [Internet]. Sao Paulo: Latin American Society of Gastroenterology, Hepatology and Nutrition; c2016 [cited 2016 Mar 21]. Available from: https://www.laspghan .org/index.php/institucion/historia-de-la-socie dad. Spanish.

7. Leichtner AM, Gillis LA, Gupta S, Heubi J, Kay M, Narkewicz MR, et al. NASPGHAN guidelines for training in pediatric gastroenterology. J Pediatr Gastroenterol Nutr. 2013 Jan;56 Suppl 1:S1-8.

8. Sherman PM, Grand RJ. Research agenda for pediatric gastroenterology, hepatology and nutrition. Introduction: report of the North American Society for Pediatric Gastroenterology, Hepatology and Nutrition for the Children's Digestive Health and Nutrition Foundation. J Pediatr Gastroenterol Nutr. 2002;35 Suppl 3:S235-6.

9. Alagille $D$, Odièvre $M$. Maladies du foie et des voies biliaires chez l'enfant. Paris: Flammarion; 1978. French.

10. Mowat AP. Liver disorders in childhood. London: Butterworth-Heinemann Ltd; 1998. 496 p.

11. Suchy FJ, Sokol RJ, Balistreri WF. Liver disease in children. 4th ed. Boston: Cambridge University Press; 2014.

12. Silverman A, Roy CC, Cozzetto FJ. Pediatric Clinical Gastroenterology. 1st. ed. St. Louis: Mosby; 1971.

13. Castañeda C. Pediatric Gastroenterology in Cuba. J Pediatr Gastroenterology Nutr. 2001 Nov;33(5):525-6.
14. Robaina Castellanos RG. A treinta años del inicio del Programa de Atención Materno Infantil en Matanzas: realidades y retos. Rev Méd Electrón [Internet]. 2014 Jan-Feb [cited 2016 Mar 21];36(1). Available from: http://www.revma tanzas.sld.cu/revista\%20medica/ano\%202014/ vol1\%202014/tema01.htm. Spanish.

15. Cooper RS, Kennelly JF, Ordunez-Garcia P. Health in Cuba. Int J Epidemiol. 2006;35:817-24

16. Castañeda C, Fragoso T, Grá B, CallejasLorensen C, Limonta M. El tratamiento con interferón leucocitario (IFN-Hu-alfa) en niños y adolescentes con hepatitis crónica activa. Archv Arg Pediatría. 1987;85:351-9. Spanish.

17. Castañeda C, Garcia E, Grá B, Moroto M, Viada C, López-Saura P. Disminución de la actividad histológica en niños con hepatitis $\mathrm{B}$ crónica con interferón alfa $2 \mathrm{~b}$ recombinante. Acta Latino-Am Gastroenterol. 2002;32(1):35-42. Spanish.

18. Castañeda C, Escobar MP, Trujillo ME, Grá B. Síndrome de Alagille en Cuba. Informe de nueve casos. GEN. 1992;46(4):341-6. Spanish.

19. Duc $\mathrm{HH}$, Hefter $\mathrm{H}$, Stremmel W, CastañedaGuillot C, Hernández Hernández A, Cox DW, et al. His1069GIn and six novel Wilson disease mutations: analysis of relevance for early diagnosis and phenotype. Eur J Hum Genet. 1998 Nov-Dec;6(6):616-23. 
20. Fragoso T, Castañeda C, Grá B. Valor del fenotipo del Sistema Pi en la deficiencia de alfa 1 antitripsina. Acta Latino-Am Gastroenterol. 1986;16:75-89. Spanish.

21. Marimón Torres N, Torres Martínez E. Impact of the US economic, financial and commercial blockade in the normal health care system. Rev Cubana Salud Pública [Internet]. 2013 Apr-Jun [cited 2016 Mar 21];39(2):298-313. Available from: http://scielo.sld.cu/scielo.php?pid=S0864-346620 $13000200010 \&$ script=sci arttext. Spanish.

22. Anales del 1er. Congreso Peruano de Gastroenterología Pediátrica y Nutrición. Lima: [publisher unknown]; 2001. Spanish.

23. Calva R, editor. Gastroenterología y Nutrición Pediátrica. México DF: Editorial McGraw-Hill; 2004. Spanish.

24. Endoscopia Pediátrica. Dias Da Silva MDA, Milward G, editors. Brazilia: Editorial Guanabara Koogan; 2004. Spanish.

25. Velasco CA, editor. Enfermedades Digestivas en el Niño. Cali: Editorial Universidad del Valle de Cauca; 2006. Spanish.

26. Hernández J, Samada M, editors. Hepatología. Sección de Hepatología Pediátrica. Havana: Editorial CIMEQ; 2006. Spanish.

27. La Torre E, González-Posadas EP. Tratado de Pediatría. Havana: Editorial Ciencias Médicas; 2010. Spanish.

28. Handbook of Growth and Growth Monitoring in Health and disease. London: Springer ScienceBusiness Media; 2011.

29. Sagaró E. Diarrea Persistente. Fundamentos de la enfermedad y enfoque terapéutico. Berlin: Editorial Académica Española; 2012. Spanish.

30. Coto C, editor. Reumatología Pediátrica. Havana: Editorial Ciencias Médicas; 2012. Spanish.

31. Zayas G. Alimentación y Nutrición. Havana: Nutrition and Food Hygiene Institute; 2013. Spanish.

32. Paniagua M, Piñol F, editors. Tratado Gastroenterología y Hepatología Clínica. 6 Vols. Havana: Editorial Ciencias Médicas; 2014. Spanish.

33. Castañeda C. Ecosistema Intestinal. Quito: Mendieta-UNIANDES; 2014. Spanish.

34. Castañeda C, del Monte A. Prebióticos. Obtención y repercusión en la salud. Quito: Editorial Mendieta-UNIANDES; 2014. Spanish.
35. Blanco-Rabasa E, Sagaró E, Fragoso T, Castañeda C, Valenti J. Enfermedad celíaca. Rev Cubana Pediatr. 1973;47:209-29. Spanish.

36. Fragoso T, Blanco E, Castañeda C, Sagaró E, Grá B. Malabsorción por Giardia lamblia: Rev Cubana Pediatr. 1975;47:247-63. Spanish.

37. Fragoso T, Castañeda C, Sagaró E. Propuesta de clasificación de la repercusión intestinal de la giardiasis. Rev Cubana Med Trop. 1986;38(2):223-28. Spanish.

38. Galbán E, Bravo JR, Castañeda C, Toledo G, González-Griego A, Delgado MG. Field

39. trial of the Cuban recombinant vaccine against hepatitis B (Heberbiovac HB). Study in newborn infants. Rev Cubana Med Trop. 1992;44(2):149-57.

40. Blanco-Rabasa E, Sagaró E, Fragoso $T$, Castañeda, Grá B. Demostración de la enfermedad celíaca en Cuba. Bol Hosp Inf Mex 1980;37:689-95. Spanish

41. Castañeda C, Fragoso T, Blanco E, Grá B. Hepatitis crónica en el niño. Bol Hosp Inf Mex 1980;27(4):587-95. Spanish.

42. Blanco-Rabasa E, Sagaró E, Fragoso T, Castañeda C, Grá B. Coeliac disease in Cuban children. Arch Dis Childhood. 1981 Feb;56(2):128-31.

43. Castañeda C, Fragoso T. Intéret de la laparoscopie pour le diagnostic des cholestases du nourrison. Ann Pediatr (Paris). 1984 Jan;31(1):29-31. French.

44. Fragoso $\mathrm{T}$, Castañeda C, Castellanos O, Grá B. Síndrome de Peutz-Jeghers. Presentación de dos casos. Brasilia Médica. 1986;21:26-8. Spanish.

45. Castañeda C. Ecosistema Intestinal. Arch Gastroenterol Rep Dominicana.1996;4:41-56. Spanish.

46. Castañeda C, Delgado G, Galindo M. Nationa Hepatitis B Vaccination Program for children and adolescents in Cuba. J Pediatr Gastroenterol Nutr. 2000;312 (Suppl 2):S199.

47. Vandenplas I, Ramírez-Mayans J, Castañeda C. Consenso sobre el uso de probióticos en Pediatría. Rev Enferm Infecciosas (México). 2002;XV(60):144-53. Spanish.

48. Castaneda C, Alvarez-Fumero R, Sorell L, Galvan JA, Carvajal F. Screening for Coeliac
Disease in Risk Groups in Cuba. J Pediatr Gas troenterol Nutr. 2004; 39(5):S211-2.

49. Yamashiro Y, Castañeda C, Davidson G, Gibson G, Penna FJ, Mack D, et al. Biotherapeutic and nutraceutical agents. Report of Working Group of the Second World Congress of Pediatric Gastroenterology, Hepatology, and Nutrition. J Pediat Gastroenterol Nutr. 2004;39 (Suppl 2):S596-600.

50. Castañeda C, Delgado G, Galindo MA. Impact of vaccination in the elimination of hepatitis $B$ in children $<5$ years. (1992-04). J Pediatr Gastroenterol Nutr. 2005;41(4):524

51. Cintado A, Sorell L, Galván JA, Martínez L, Castaneda C, Fragoso T, et al. HLA DQA 1* 0501 and DQB1* 02 in Cuban celiac patients. Hum Immunol. 2006;56;639-42.

52. Brizuela Quintanilla RA, Ruiz Torres JF, Ramos Contreras JY, García-Menocal Hernández J, Alonso Contino N. Tratamiento endoscópico de afecciones biliopancreáticas en niños. Análisis de 31 pacientes. Endoscopía. 2016 JanMar;28(1):16-20. Spanish.

53. Gorry C. Lowering Infant Mortality in Cuba MEDICC Rev. 2015 Jan;17(1):11-3.

\section{THE AUTHOR}

Carlos Castañeda-Guillot (ccastanedag14@ gmail.com). Physician specializing in pediatric gastroenterology. Consulting professor and senior researcher, Calixto García Medical Faculty, Medical University of Havana, Cuba. Principal professor and research analyst, Faculty of Medicine, Autonomous Regional University of Los Andes, Quito, Ecuador.

Submitted: June 4, 2015

Approved for publication: September 30, 2016

Disclosures: Dr Castañeda-Guillot was one

of the first three Cuban physicians trained in pediatric gastroenterology, mentioned in the article. 